$\begin{array}{cc}\text { ACADEMIA ROMÂNĂ } & \text { Rev. Roum. Chim., } \\ \text { Revue Roumaine de Chimie } & \text { 2019, 64(7), 615-623 } \\ \text { http://web.icf.ro/rrch/ } & \text { DOI: 10.33224/rrch.2019.64.7.08 }\end{array}$

\title{
BENZIMIDAZOLE SCHIFF BASES MICROWAVE ASSISTED SYNTHESIS AND THE EFFECT ON LEUKEMIA CELLS WITH FLOW CYTOMETRY
}

\author{
Seyma CELIKBILEK CELIK ${ }^{\mathrm{b}}$, Husamettin VATANSEV ${ }^{\mathrm{c}}$ and Ziya Erdem KOC ${ }^{\mathrm{a}^{*}}$ \\ ${ }^{a}$ Department of Chemistry, Faculty of Science, Selcuk University, Konya, 42031, Turkey \\ ${ }^{b}$ Department of Clinical Immunology and Allergy, Faculty of Medicine, Necmettin Erbakan University, \\ Konya 42090, Turkey \\ ${ }^{\mathrm{c}}$ Department of Medicinal Biochemistry, Faculty of Medicine, Selcuk University, Konya, 42031, Turkey
}

Received April 14, 2018

\begin{abstract}
The present paper introduces a simple and efficient method for the synthesis of a 2-aryl-substituted benzimidazole by heterocyclization of 1,2phenylenediamine and 5-aminoisophthalic acid in the presence of polyphosphoric acid as catalyst under solvent-less conditions, which produced good yield of corresponding benzimidazoles in a short reaction time. Two new bisbenzimidazoles and tetrakisbenzimidazole Schiff bases were synthesized by reaction between 3,5-di( $1 H$-benzo[d]imidazol-2-yl)aniline (BIMA) and terephthalaldehyde or 4-formylbenzoic acid. The condensations proceed in short time to give products which, in certain instances, are not readily attainable by conventional condensation techniques. Due to its good performance, the microwave device used in household was preferred. The structures of the compounds were assigned by FT-IR, ${ }^{1} \mathrm{H}$ NMR, ${ }^{13} \mathrm{C}$ NMR and elemental analysis. The effects of benzimidazoles and Schiff bases on the cancerous cells have been known. Synthesized by bisbenzimidazole and bisbenzimidazole/tetrakisbenzimidazole-Schiff bases derivatives 3,5-di $(1 H$ benzo[d]imidazol-2-yl)aniline (BIMA), N,N'-(1,4-phenylenebis(methan-1-yl1-ylidene))bis(3,5-di(1H-benzo[d]imidazol-2-yl)aniline) (PM-BIMA), (E)-4((3,5-di(1H-benzo[d]imidazol-2-yl)phenylimino)methyl)benzoic acid (BIMPMBA) with flow cytometric analysis was performed, blastic cells containing $90 \%$. We measured rates of cell death in cells blast on the matter.
\end{abstract}

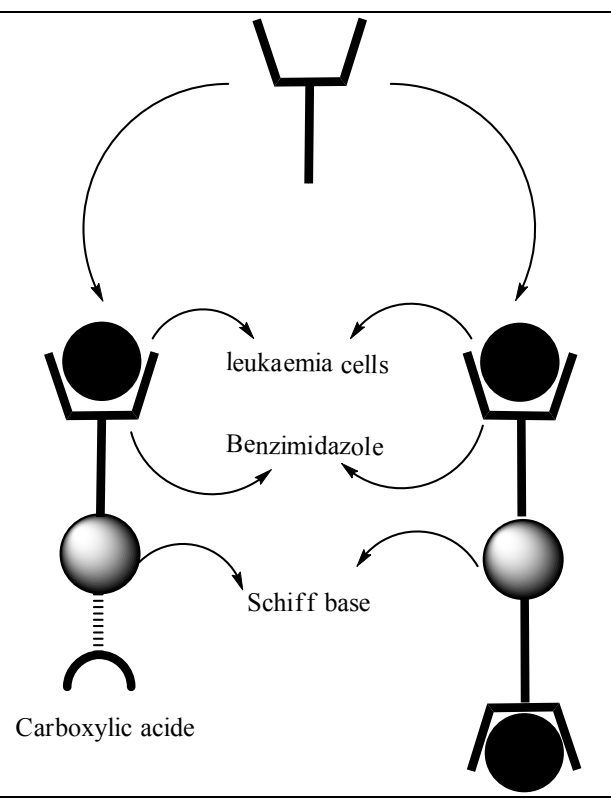

\section{INTRODUCTION}

Benzimidazoles and their derivatives are important classes of heterocyclic molecules in several field of organic chemistry. ${ }^{1-5}$ Bisbenzimidazole and bisbenzimidazole/tetrakisbenzimidazole-Schiff bases derivatives are key components in a large number of bioactive compounds of both natural and synthetic origin. ${ }^{6-12}$ They are a common heterocyclic scaffold in biologically active and medicinally significant compounds $^{13,14}$ and are found in many natural products. ${ }^{15}$ Moreover, these groups of heterocyclic compounds exhibit a wide range of pharmacological properties, which include antiviral, ${ }^{16}$ anticancer, ${ }^{17-19}$ antimicrobial, ${ }^{20-23}$ antitumor ${ }^{24-25}$ antifungal, ${ }^{26-27}$ antiinflammatory activity, ${ }^{28-29}$ anti-parasitic, ${ }^{30,31}$ antibacterial, ${ }^{32}$ and many others properties. Benzimidazoles have shown exciting and diverse biological and pharmaceutical properties and are therefore considered privileged structures in the design and discovery of new drugs. ${ }^{33}$ 
The compounds with imine group in their structure, known as Schiff bases, are synthesized by the condensation reaction of the amines with the carbonyl groups. ${ }^{34}$ Schiff bases of benzimidazole have been reported with remarkable antibacterial ${ }^{35}$ and antimicrobial activities. ${ }^{36-37}$ Traditionally, bisbenzimidazoles were most often been prepared from the reaction of o-phenylenediamine with 5-aminoisophtalic acid under harsh dehydrating conditions, using strong acids. ${ }^{38-39}$ However, Microwave-assisted organic synthesis (MAOS) continues to affect synthetic chemistry significantly by enabling rapid, reproducible experiments. ${ }^{40-43}$ Particularly, the use of milder reagents has improved both the yield and purity of this reaction. ${ }^{44-45}$ Today, cancer patients are being treated with radiotherapy, chemotherapy and surgical interventions. ${ }^{46}$ It is known that the procedures applied in this process are heavy for the patient. Since chemotherapy drugs kill both live and cancer cells the patient's immune system weakens. Therefore, the effect of bisbenzimidazole/tetrakisbenzimidazole-Schiff bases on cancer cells being well known, we have planned to obtain Schiff bases from benzimidazole in order to protect live cells, and to study the effect of leukemia cells on flow cytometry. In the patients diagnosed with leukemia, the appropriate panels were studied by applying the synthesized substances as a $10 \%$ solution to cells and the measurements were recorded in the device. ${ }^{47}$ The present study reports a method for achieving bisbenzimidazole/ tetrakisbenzimidazole-Schiff base systems formed by condensation reaction 3,5-di( $1 H$ benzo[d]imidazol-2-yl)aniline (BIMA). Herein, we reported the synthesis BIMA $^{48}$ and its bisbenzimidazole/tetrakisbenzimidazole-Schiff base as a new template. We envisioned that microwave irradiation would enhance this chemistry and expand the chemistry scope. ${ }^{49-51}$

\section{RESULTS AND DISCUSSION}

\section{3,5-di(1H-benzo[d]imidazol-2-yl)aniline (BIMA)} was prepared by the reaction of 1,2-phenylenediamine with 5-aminoisophthalic acid (Scheme 1, Fig. 1). The structural formula of the 3,5-di( $1 \mathrm{H}-$ benzo[d]imidazol-2-yl)aniline (BIMA) was verified by elemental analysis, ${ }^{1} \mathrm{H}$ NMR and FT-IR. ${ }^{48,52}$ (1,4-Phenylenebis(methylylidene))bis(3,5-di(1H- benzimidazole-2-yl)aniline) (PM-BIMA) and (E)-4-((3,5-di(1H-benzo[d]imidazol-2-yl) phenylimino)methyl)benzoic acid (BIM-PMBA) were synthesized by the reaction of 3,5-di( $1 H$ benzo[d]imidazol-2-yl)aniline (BIMA) with terephthalaldehyde and 4-formylbenzoic acid. (Scheme 2). ${ }^{53,54}$

These compounds were characterized by their elemental analysis, ${ }^{1} \mathrm{H}$ NMR, ${ }^{13} \mathrm{C}$ NMR and FT-IR. Because of replacement of the carbonyl by the imines groups, the band at $1665 \mathrm{~cm}^{-1}$ for the $\mathrm{C}=\mathrm{O}$ stretch in the FT-IR spectrum disappeared and appeared at $1686-1673 \mathrm{~cm}^{-1}$ for azomethine $\mathrm{C}=\mathrm{N}$ group PM-BIMA and BIM-PMBA, respectively. In the ligand BIM-PMBA, the band at $3055 \mathrm{~cm}^{-1}$ can be assigned to the -OH group vibrations. To identify the structures of BIMA, PM-BIMA and BIM-PMBA, the ${ }^{1} \mathrm{H}$ NMR spectra were recorded in DMSO-d $\mathrm{d}_{6}{ }^{1} \mathrm{H}$ NMR data were also in good correlation with the structures of the synthesized compounds. The ${ }^{1} \mathrm{H}$ NMR spectrum signals of ligands BIM-PMBA and PM-BIMA at $\delta$ (ppm), 10.05-10.13 ppm, correspond to the $-\mathrm{NH}$ proton, respectively (Fig. 2 and Fig. 3). The signal for $\mathrm{HC}=\mathrm{O}$ group disappeared and gave the signal at higher frequency for the $-\mathrm{CH}=\mathrm{N}$ and $-\mathrm{OH}$ proton in the ${ }^{1} \mathrm{H}$ NMR spectrum. The signals of ${ }^{13} \mathrm{C}$ NMR spectrum of BIM-PMBA (Fig. 2) were in a good agreement with the proposed formula. The "benzimidazole Schiff bases" prepared in this way was obtained in nearly quantitative yield and high purity. ${ }^{6-12,53,54}$

Flow cytometry ${ }^{47}$ was conducted to investigate cell death of bisbenzimidazole and bisbenzimidazole/tetrakisbenzimidazole-Schiff base derivatives on CD34 including cancer cells. As shown in Fig. 4, Fig. 5 and Fig. 6 according to measurements. The cavity between the benzimidazole ligands is thought to be suitable for the diameter of the leukemia cells (Scheme 3).

First tube shows the values that are leukemia blast cells. Vital CD34 cells/microliters: 18039.65/ microliters and Viable CD45 cells/microliters: 33901.39/microliters. If we take this as the standard, we can observe the exchange of added substances to tube two and tube three on the blast cells. Added to the second tube "PM-BIMA"s effect on the "Viable CD34 cells/microliters:974.36/microliters and Vital CD45cells/microliters:40696.39/microliters (Table 1). 

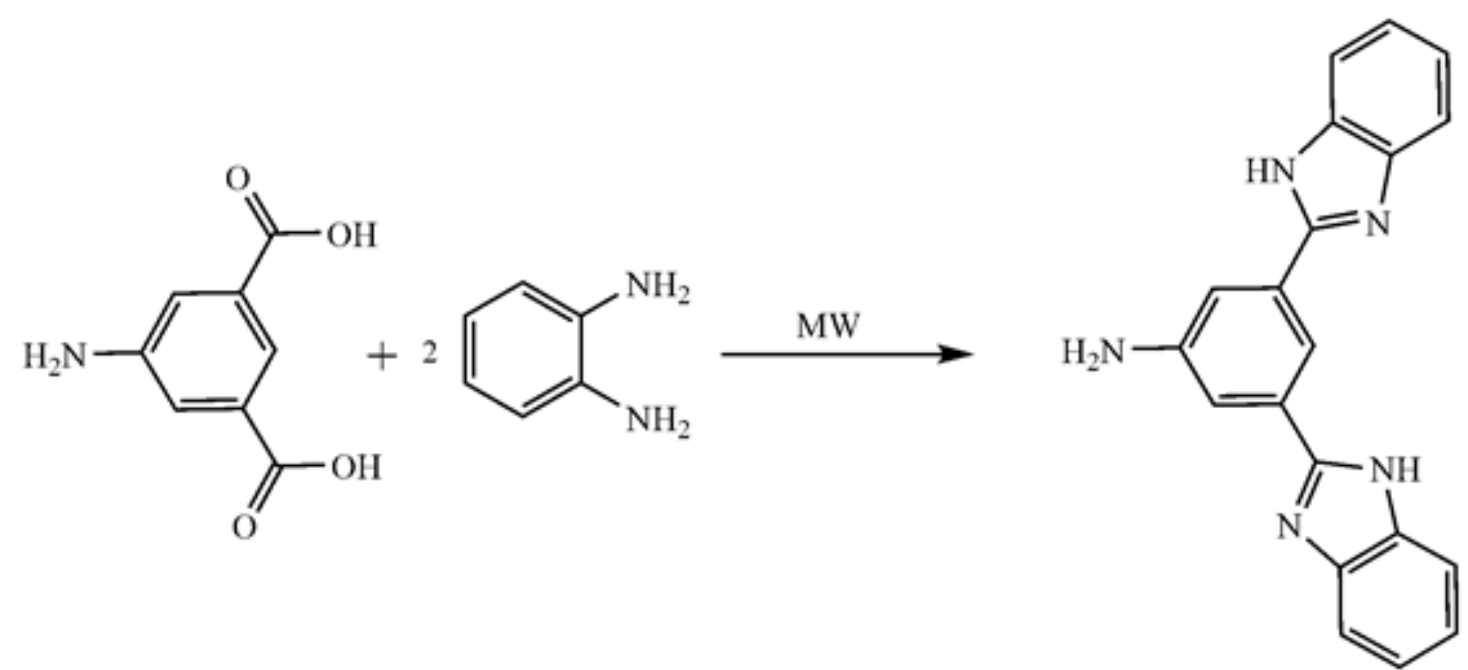

Scheme 1 - Proposed structures of the microwave-assisted bisbenzimidazole formation (BIMA).

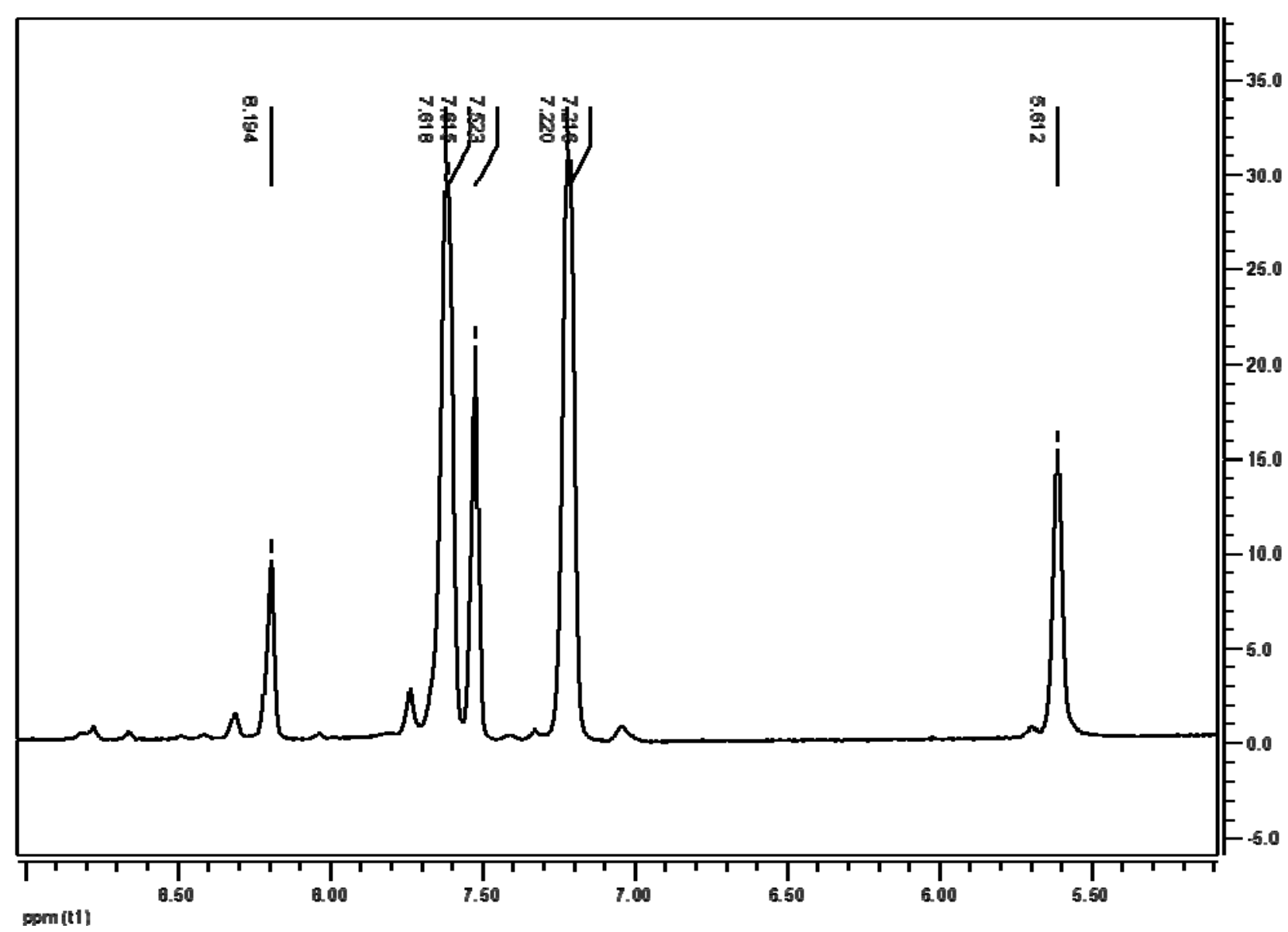

Fig. 1 - ${ }^{1}$ H NMR Spectrum of 3,5-di(1H-benzo[d]imidazol-2-yl)aniline (BIMA). 

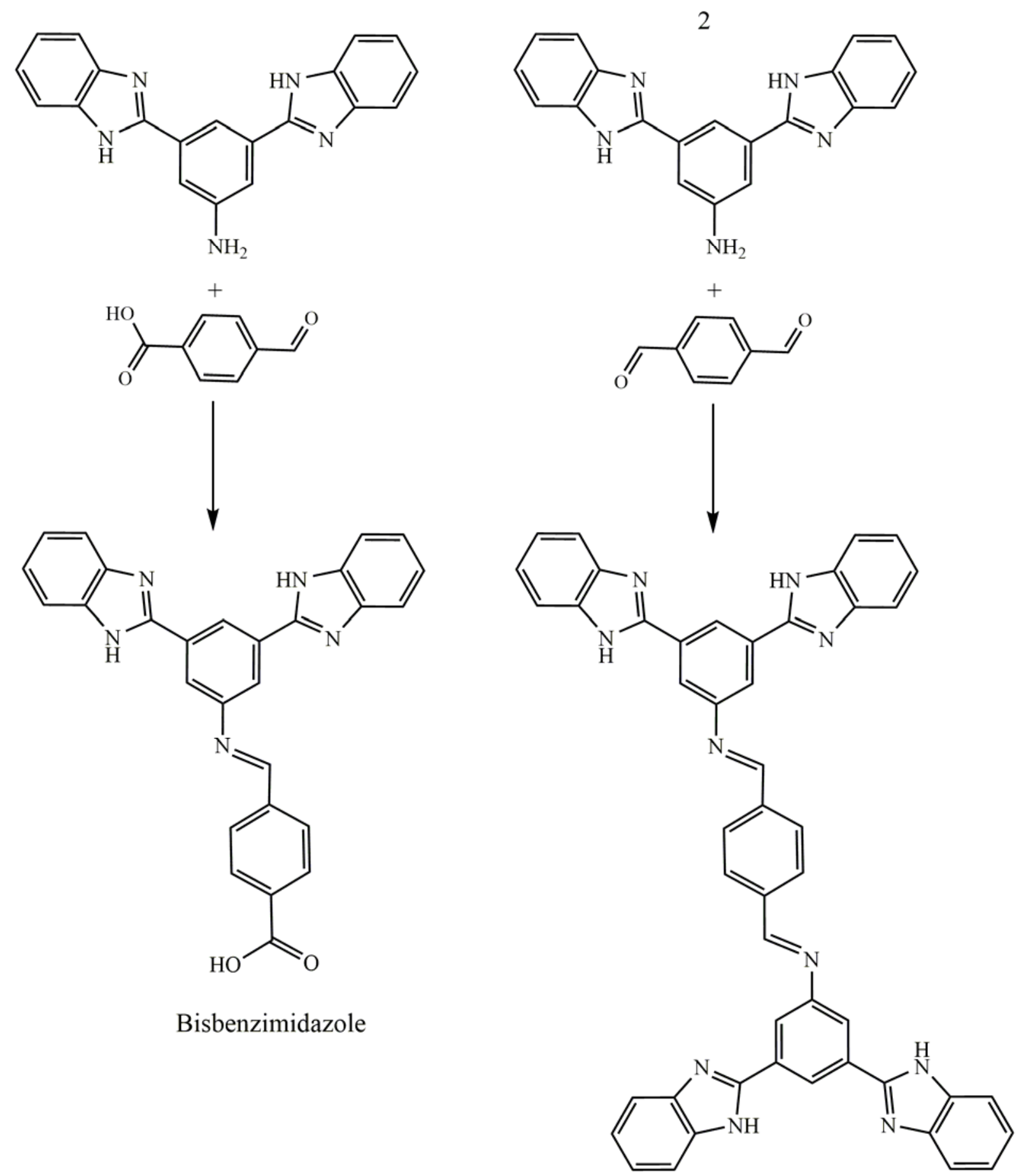

Bisbenzimidazole

Tetrakisbenzimidazole

Scheme 2 - Proposed structures of the microwave-assisted bisbenzimidazole/tetrakisbenzimidazole Schiff bases. 


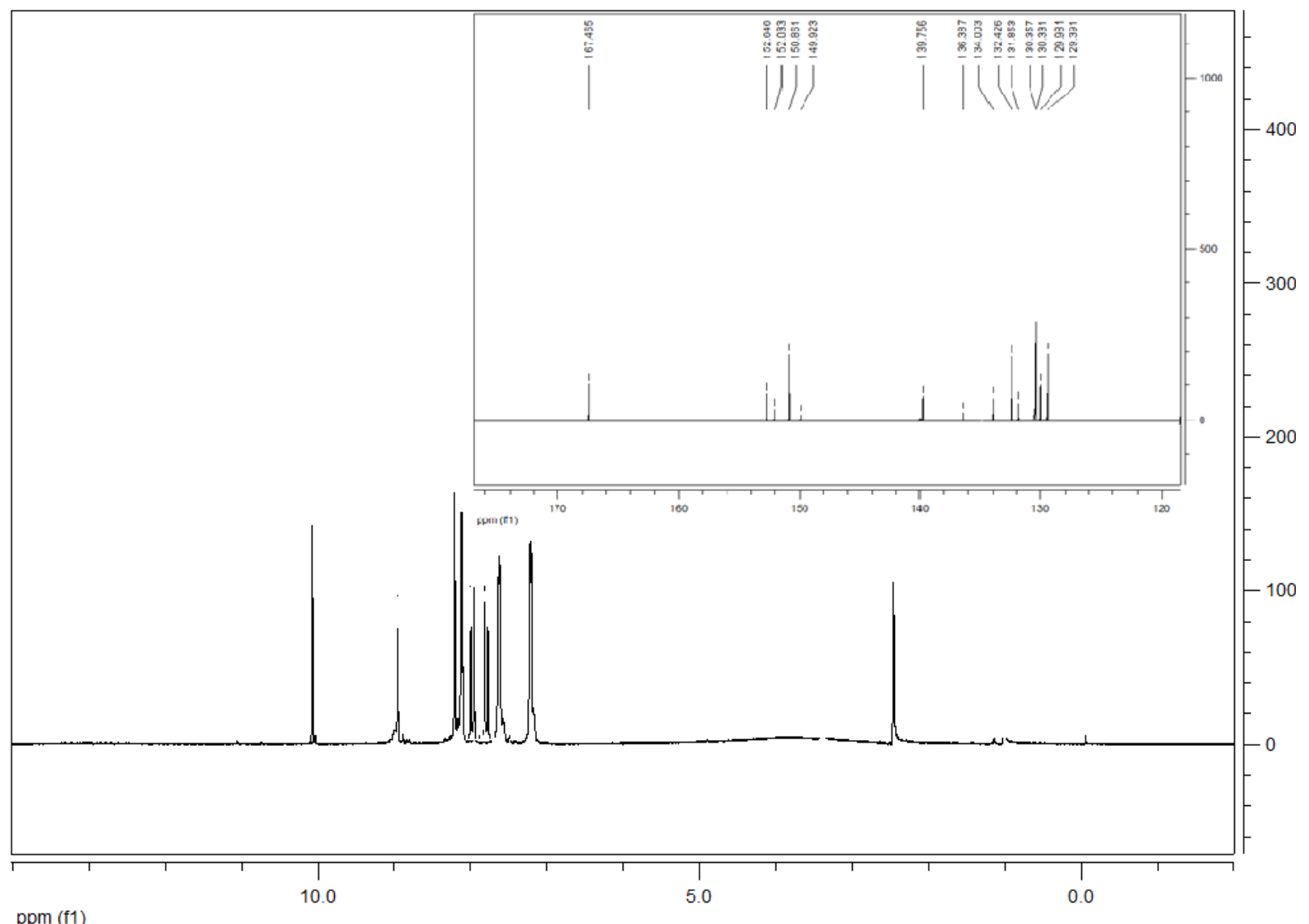

Fig. $2-{ }^{1} \mathrm{H}-{ }^{13} \mathrm{C}$ NMR Spectrum of 4-((3,5-di(1H-benzimidazol-2-yl)phenylimino)methyl)benzoic acid (BIM-PMBA).

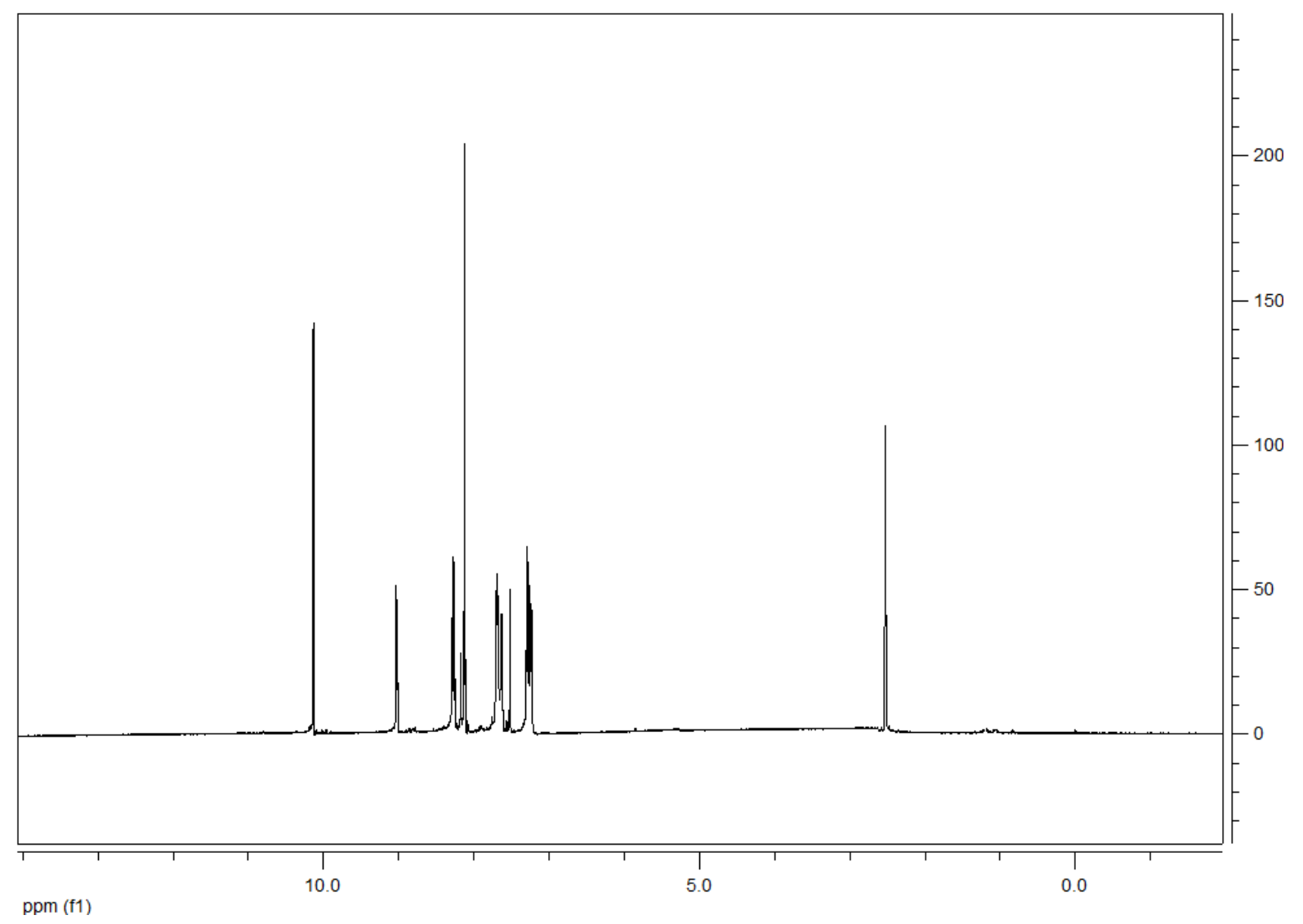

Fig. 3 - ${ }^{1}$ H NMR Spectrum of N,N'-(1,4-phenylenebis(methan-1-yl-1-ylidene))bis(3,5-di(1H-benzo[d]imidazol-2-yl)aniline)) (PM-BIMA). 


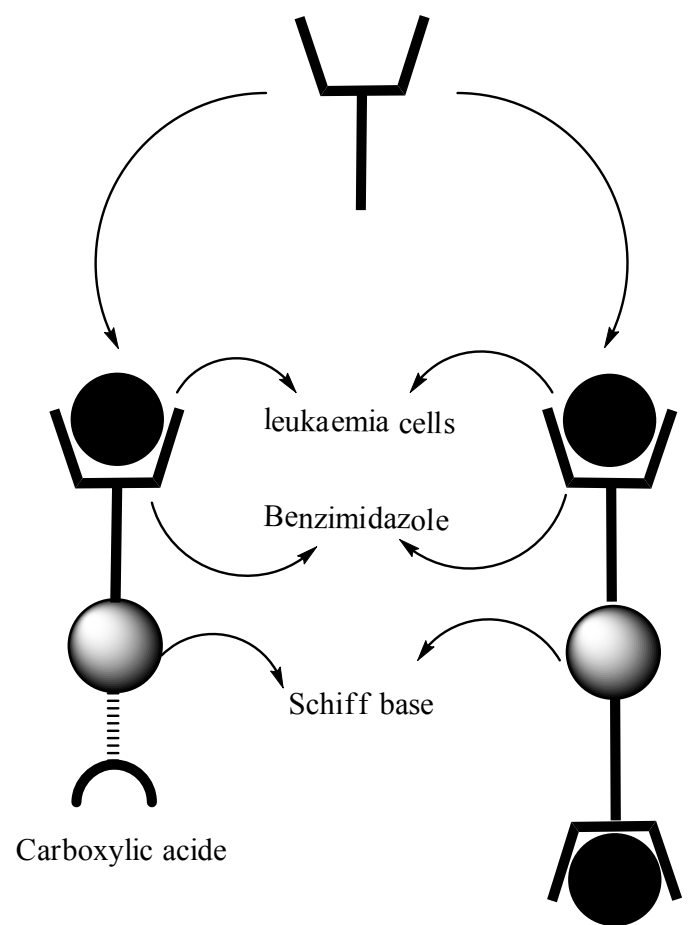

Scheme 3 - The bisbenzimidazole/tetrakisbenzimidazole-Schiff bases and leukaemia cells.

Table 1

Gate statistics

\begin{tabular}{|c|c|c|c|}
\hline \multirow{2}{*}{\multicolumn{2}{|c|}{ Gate Statistics AML Sample }} & \multirow{2}{*}{$\begin{array}{c}\text { AML Sample } \\
\text { PM-BIMA }\end{array}$} & \multirow{2}{*}{$\begin{array}{c}\text { AML Sample } \\
\text { BIM-PMBA }\end{array}$} \\
\hline & & & \\
\hline Alive CD34 Cells $/ \mu \mathrm{L}$ & 18039.65 & 974.36 & 7015.67 \\
\hline Alive CD45 Cells $/ \mu \mathrm{L}$ & 33901.39 & 40696.39 & 20163.89 \\
\hline Total CD34 Cells $/ \mu \mathrm{L}$ & 24367.57 & 12034.09 & 19827.96 \\
\hline The alive percentage of CD45 & $73.87 \%$ & $8.08 \%$ & $35.38 \%$ \\
\hline The alive percentage of CD34, CD45 & $0.04 \%$ & $0.04 \%$ & $0.04 \%$ \\
\hline
\end{tabular}
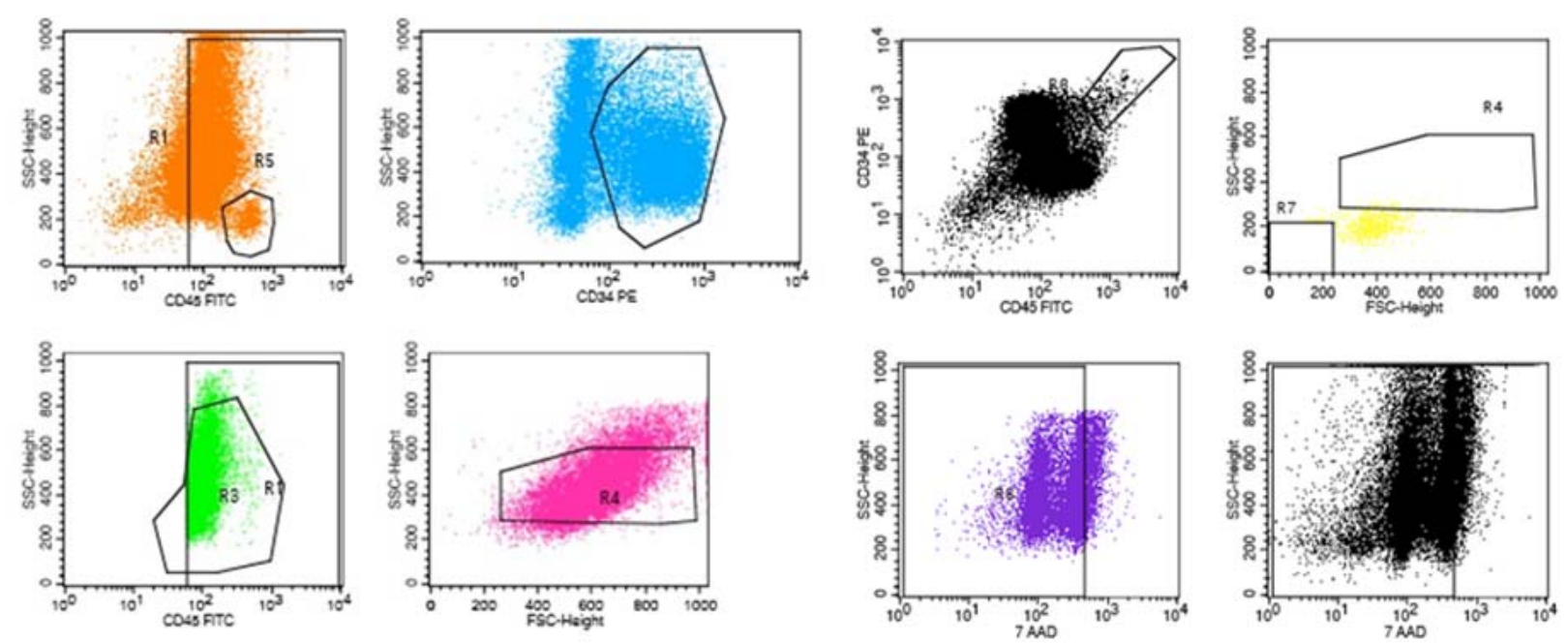

Fig. 4 - The standard values of AML sample (Tube 1). 

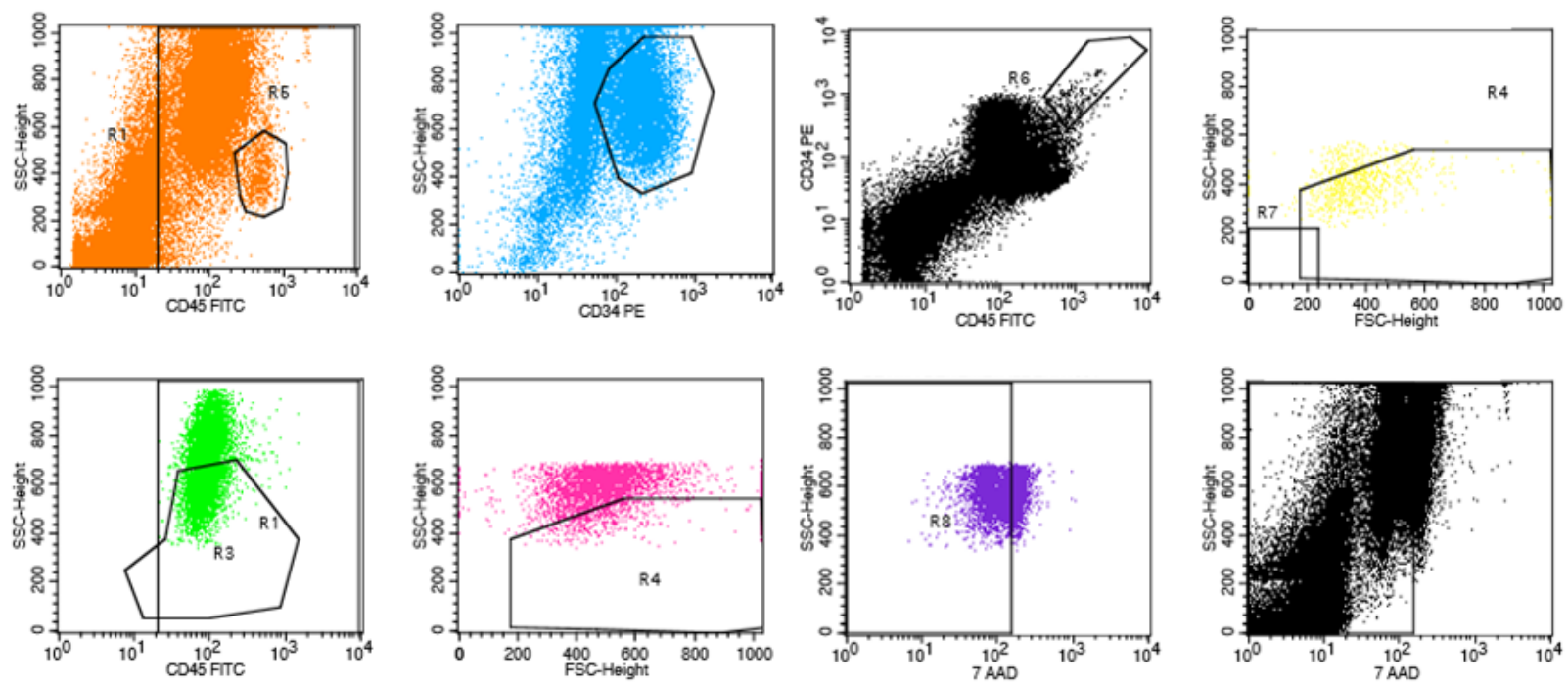

Fig. 5 - The form of the cells adding (PM-BIMA) (Tube 2).
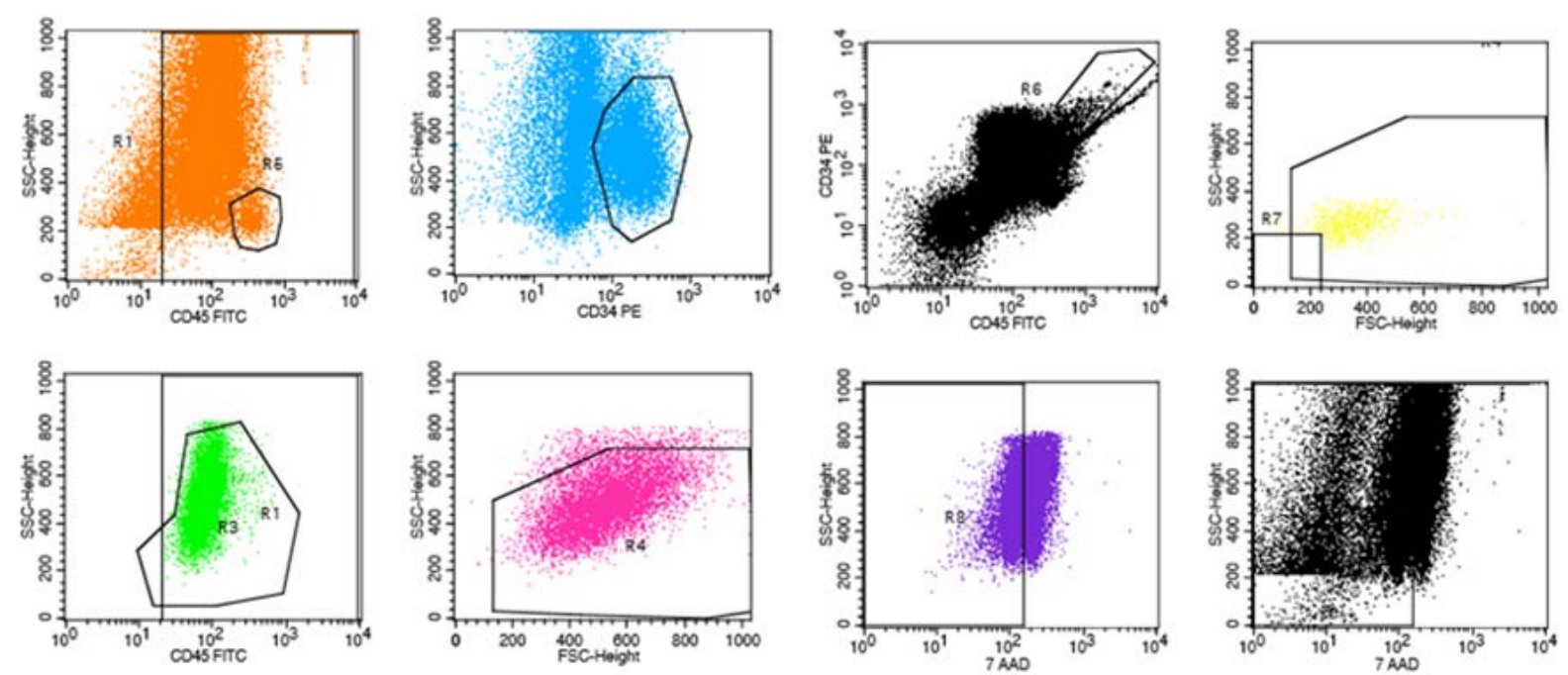

Fig. 6 -The form of the cells adding (BIM-PMBA) (Tube 3).

Added to the third tube "BIM-PMBA"s effect on the Viable CD34 cells/microliters: 7015.67/microliters and Viable CD45 cells/microliters:20163.89/microliters (Table 1).

Identified CD34 cells in AML patients are blast cells. CD45 cells are antibodies that must be presented in every human body. Total cells death is determined with 7AAD also.

\section{EXPERIMENTAL}

\section{Materials and Methods}

All the chemicals and solvents used for this work were purchased from Sigma Aldrich. LG-health wave microwave system (MG-607APR, 230V-50Hz) was used and the output of microwave power is mentioned as percent intensity i.e. $(20 \%, 40 \%, 60 \%, 100 \%)$. Melting points were measured using an Optimelt Automated Melting Point System (Digital Image Processing Technology) SRS apparatus. Elemental analyses $(\mathrm{CHN})$ were performed using a Leco, CHNS-932 model analyzer. ${ }^{1} \mathrm{H}$ NMR spectra were recorded at room temperature with a Varian, $400 \mathrm{MHz}$ spectrometer using TMS as an internal standard. FT-IR spectra were recorded with a PerkinElmer Spectrum 100 with Universal ATR Polarization Accessory. The $\mathrm{pH}$ values were measured with a WTW $\mathrm{pH}$ $537 \mathrm{pH}$ meters. Flow cytometry was used to influence the substance of blast cells. A reaction mixture of o-phenylenediamine and appropriate acid was subjected to microwave irradiation at $350 \mathrm{~W}$ for 25 minutes. Completion of the reaction was monitored by TLC.

Preparation of Microwave Assisted 3,5-di(1Hbenzo[d]imidazol-2-yl)aniline (BIMA). Equimolar amounts of o-pheylenediamine and the 5-aminoisophthalic acid were mixed with a sufficient quantity of polyphosphoric acid to give a stirrable paste. The mixture was heated using microwave irradiation technique at $350 \mathrm{~W}$ for 25 minutes, permitted to cool, and poured in a thin stream into a large 
volume of rapidly stirred water. The insoluble residue was collected by filtration, washed with a small amount of water and reslurried in an excess of $10 \%$ sodium carbonate solution. The alkaline slurry was filtered and the product washed thoroughly with water. The product was recrystallized from alcohol or an aqueous alcohol mixture after treatment with a small amount of activated charcoal. Completion of the reaction was monitored by TLC. (BIMA); Yield: $60 \%$. The $\mathrm{CHN}$ analyses of the compound corresponded to the molecular formula $\mathrm{C}_{20} \mathrm{H}_{15} \mathrm{~N}_{5}$. Elemental analysis was found as: $\mathrm{C}, 73.83$; H, 4.62; N, 21.49\%. Calc.: C, 73.83; H, 4.65; N, 21.52; \%. FTIR $\left(\mathrm{cm}^{-1}\right): 3048(\mathrm{NH}), 1606(\mathrm{C}=\mathrm{C}), 1450$ (hetero-ring). ${ }^{1} \mathrm{H}$ NMR (400 MHz, DMSO-d ${ }_{6}$ ) ( $\left.\delta: \mathrm{ppm}\right): 8.19$ (s, H, $\mathrm{CH}_{\text {arom }}$ ), 7.62-7.61 (d, 4H, $\left.\mathrm{CH}_{\text {arom }}\right), 7.52\left(\mathrm{~s}, 2 \mathrm{H}, \mathrm{CH}_{\text {arom }}\right), 7.22-7.21(\mathrm{~d}$, $\left.4 \mathrm{H}, \mathrm{CH}_{\text {arom. }}\right), 5.61\left(\mathrm{~s}, 2 \mathrm{H}, \mathrm{NH}_{2}\right)$. phenylenebis(methan-1-yl-1-ylidene))bis(3,5-di(1Hbenzo[d]imidazol-2-yl)aniline)) (PM-BIMA) and 4-((3,5di(1H-benzimidazol-2-yl)phenylimino)methyl)benzoic acid (BIM-PMBA). The Schiff bases, PM-BIMA and BIMPMBA were obtained as solids by refluxing a mixture of (BIMA) (7.81 g; $24 \mathrm{mmol})$ and terephthalaldehyde (1.60 g; $12 \mathrm{mmol}$ ) or (BIMA) $(3.25 \mathrm{~g} ; 10 \mathrm{mmol})$ and 4-formylbenzoic acid $(1.50 \mathrm{~g} ; 10 \mathrm{mmol})$ in ethanol $(35 \mathrm{~mL})$ which was heated using microwave irradiation technique at $350 \mathrm{~W}$ for about 25 minutes. The solid was washed with ether and recrystallized from ethanol and dried under vacuum. (PMBIMA); Yield: $65 \%$; m.p.: $310^{\circ} \mathrm{C}$; The $\mathrm{CHN}$ analyses of the compound corresponded to the molecular formula $\mathrm{C}_{48} \mathrm{H}_{32} \mathrm{~N}_{10}$. Elemental analysis was found as: $\mathrm{C}, 76.94 ; \mathrm{H}, 4.34 ; \mathrm{N}$, 18.68\%. Calc.: C, 76.99; H, 4.31; N, 18.70. FT-IR $\left(\mathrm{cm}^{-1}\right): 2816$ $(\mathrm{NH}), 1686\left(\mathrm{CH}=\mathrm{N}_{\text {imine }}\right), \quad 1498\left(\mathrm{C}=\mathrm{N}_{\text {heterocyclic }}\right) .{ }^{1} \mathrm{H} \quad \mathrm{NMR}$ $\left(400 \mathrm{MHz}, \mathrm{DMSO}-\mathrm{d}_{6}\right)(\delta: \mathrm{ppm}): 10.13(\mathrm{~s}, 4 \mathrm{H}, \mathrm{NH}), 9.03$ (s, $2 \mathrm{H}, \mathrm{CH}=\mathrm{N}), 8.30$ (m, $4 \mathrm{H}, \mathrm{CH}_{\text {arom }}$ ), 8.10 (s, $4 \mathrm{H}, \mathrm{CH}_{\text {arom }}$ ), 7.70 $\left(\mathrm{m}, 8 \mathrm{H}, \mathrm{CH}_{\text {arom. }}\right), 7.50\left(\mathrm{~s}, 2 \mathrm{H}, \mathrm{CH}_{\text {arom }}\right), 7.61-7.03(\mathrm{~m}, 8 \mathrm{H}$, $\mathrm{CH}_{\text {arom.). }}$ (BIM-PMBA) Yield: $70 \%$; m.p.: $298{ }^{\circ} \mathrm{C}$; The $\mathrm{CHN}$ analyses of the compound corresponded to the molecular formula $\mathrm{C}_{28} \mathrm{H}_{19} \mathrm{~N}_{5} \mathrm{O}_{2}$, Found: $\mathrm{C}, 73.50 ; \mathrm{H}, 4.22 ; \mathrm{N}, 15.28 ; \mathrm{O}$, 6,93\%. Calc.: C, 73.51; H, 4.19; N, 15.31; O, $6.91 \%$. FTIR $\left(\mathrm{cm}^{-1}\right): 3055(\mathrm{OH}), 3320(\mathrm{NH}), 1673\left(\mathrm{CH}=\mathrm{N}_{\text {imine }}\right), 1600$ $(\mathrm{C}=\mathrm{C}), 1538\left(\mathrm{C}=\mathrm{N}_{\text {heterocyclic }}\right), 1281\left(\mathrm{C}-\mathrm{O}_{\text {Phenolic }}\right) .{ }^{1} \mathrm{H}$ NMR $(400$ MHz, DMSO-d $\left.{ }_{6}\right):(\delta: \mathrm{ppm}): 10.05(\mathrm{~s}, 2 \mathrm{H}, \mathrm{NH}), 8.95(\mathrm{~s}, \mathrm{H}$, $\mathrm{CH}=\mathrm{N}), 8.20$ (s, H, $\left.\mathrm{CH}_{\text {arom }}\right), 8.12-8.10\left(\mathrm{~d}, 2 \mathrm{H}, \mathrm{CH}_{\text {arom }}\right), 7.96$ $7.94\left(\mathrm{~d}, 2 \mathrm{H}, \mathrm{CH}_{\text {arom }}\right), 7.92-7.90\left(\mathrm{~d}, 2 \mathrm{H}, \mathrm{CH}_{\text {arom }}\right), 7.63-7.61$ $\left(\mathrm{m}, 4 \mathrm{H}, \mathrm{CH}_{\text {arom. }}\right), 7.22-7.20$ (m, $\left.4 \mathrm{H}, \mathrm{CH}_{\text {arom. }}\right) .{ }^{13} \mathrm{C} \mathrm{NMR}$ $\left(100 \mathrm{MHz}, \mathrm{DMSO}-\mathrm{d}_{6}, 25{ }^{\circ} \mathrm{C}\right)(\delta: \mathrm{ppm}): 167.46,152.64$, $152.03,150.86,149.92,139.75,136.38,134.00,132.42$, $130.35,130.33,129.98,129.39$.

The effects of substances on blast cells by flow cytometry: Materials were solved in ethanol in three different tubes. On the other hand, we used the blood samples containing $90 \%$ blasts. We have prepared three different flow cytometry tubes. We've also added $20 \mu \mathrm{l}$ "CD34/CD45/7AAD" surface markers into tubes each containing $100 \mu \mathrm{l}$ of blood. We waited 20 minutes. We prepared lysing solution $(20 \mu 1$ lysing solution/ $1800 \mu \mathrm{l}$ of water) and we added it to the tubes $(2000 \mu \mathrm{l})$. We left 10 minutes of incubation in the dark. Then we washed the cells and divided it into three tubes: (1) tube; We studied the flow cytometry device, we recorded values. This value refers to the patient's percentage of "CD34" (Blast cells) before the addition of substances (Fig. 4); (2) tube; "PMBIMA (10\%)" have added, after five minutes we did the measurement in flow cytometry, we recorded values (Fig. 5); (3) tube; "BIM-PMBA (10\%)" have added, after 5 minutes we did the measurement in flow cytometry, we recorded values (Fig. 6).

\section{CONCLUSIONS}

In this study, N,N'-(1,4-phenylenebis(methan1-yl-1-ylidene))bis(3,5-di(1H-benzo[d]imidazol-2yl)aniline)) (PM-BIMA) and (E)-4-((3,5-di(1Hbenzo[d]imidazol-2-yl)phenylimino)methyl)benzoic acid (BIM-PMBA) were synthesized by the reaction of 3,5-di(1H-benzo[d]imidazol-2yl)aniline (BIMA) with terephthalaldehyde and 4formylbenzoic acid. Compounds (PM-BIMA) and (BIM-PMBA) were originally synthesized. The structures of the compounds were assigned by FTIR, ${ }^{1} \mathrm{H}$ NMR and elemental analysis. If we look at the flow cytometry measurements, the second tube added "PM-BIMA"s molecular structure, size and the benzimidazole activity, CD34 cells were quickly killed. Four kinds of benzimidazole groups and two Schiff bases were included. The third tube added "BIM-PMBA" benzimidazole effect is half up to the "PM-BIMA". In the substances, as the benzimidazole and Schiff base increase, the effect on the blast cells also increases. We also determined that by adding "FM-BIFA" material into the second tube, the analyses with flow cytometer, the CD45 cells that must have been in all alive were increased. This material killed the blast cells and increased alive cells.

Acknowledgements: This work is supported by The Research Foundation of Selcuk University (project number: 16401145).

\section{REFERENCES}

1. M. Dey, K. Deb and S. S. Dhar, Chin. Chem. Lett., 2011, 22, 296-299.

2. D. K. Maiti, S. Halder, P. Pandit, N. Chatterjee, D. De Joarder, N. Pramanik, Y. Saima, A. Patra and P. K. Maiti, J. Org. Chem., 2009, 74, 8086-8097.

3. D. M. Wu, Y. C. Zhao, K. Zeng and G. Yang, J. Polym. Sci. Pol. Chem., 2012, 50, 4977-4982.

4. K. F. Ansari and C. Lal, Eur. J. Med. Chem., 2009, 44, 4028-4033.

5. N. M. Agh-Atabay, B. Dulger and F. Gucin, Eur. J. Med. Chem., 2003, 38, 875-881.

6. S. S. Panda, R. Malik and S. C. Jain, Curr. Org. Chem, 2012, 16, 1905-1919.

7. Z. Wang, Z. Sun, X.-Q. Hao, J.-L. Niu, D. Wei, T. Tu, J.-F. Gong and M.-P. Song, Organometallics, 2014, 33, 1563-1573.

8. F. M. Saleshier, S, Suresh, N. Anitha, J. Karim and M. C. Divakar, Euro. J. Exp. Bio., 2011, 1, 150-159. 
9. V. S. Patil, V. S. Padalkar, K. R. Phatangare, P. G. Umape, B. N. Borase and N. Sekar, J. Heterocycl. Chem., 2015, 52, 124-129.

10. D. W. Allen, J. Hawkrigg, H. Adams, B. F. Taylor, D. E. Hibbs and M. B. Hursthouse, J. Chem. Soc. Perk. T 1, 1998, 335-340.

11. Sravanthi, M. Nagaraju, N. Manikanta, K. Mogalabi, Sk. Eswaraiah and C. Bardalai, J. Chem. Pharm. Res., 2012, 4, 3832-3836.

12. X. Wen, J. E. Bakali, R. Deprez-Poulain and B. Deprez, Tetrahedron Lett., 2012, 53, 2440-2443.

13. M. Barbero, S. Cadamuro and S. Dughera, Arkivoc, 2012, 262-279.

14. A. Javid, M. M. Heravi, F. F. Bamoharram and M. Nikpour, E-J. Chem., 2011, 8, 547-552.

15. Z. E. Koc, M. O. Aladag and A. Uysal, Excli J., 2013, 12, 396-403.

16. A. S. Abd El-All, A. A. Magd-El-Din, F. A. F. Ragab, M. ElHefnawi, M. M. Abdalla, S. A. Galal and A. A. ElRashedy, Arch. Pharm., 2015, 348, 475-486.

17. S. Salahuddin, M. Shaharyar, A. Mazumder and M. J. Ahsan, Arab J. Chem., 2014, 7, 418-424.

18. B. Maji, K. Kumar, K. Muniyappa and S. Bhattacharya, Org. Biomol. Chem., 2015, 13, 8335-8348.

19. I. Yildiz-Oren, I. Yalcin, E. Aki-Sener and N. Ucarturk, Eur. J. Med. Chem., 2004, 39, 291-298.

20. Z. E. Koc, H. Bingol, A. O. Saf, E. Torlak and A. Coskun, J. Hazard. Mater., 2010, 183, 251-255.

21. Y. Ozkay, Y. Tunali, H. Karaca and I. Isikdag, Arch. Pharm. Res., 2011, 34, 1427-1435.

22. L. M. Durosinmi, A. O. Oluduro and S. A. Fasasi, Nat. Sci., 2015, 13, 1-13.

23. W. A. Denny, G. W. Rewcastle and B C. Baguley, J. Med. Chem., 1990, 33, 814-819.

24. M. Aljahdali, Spectrochim. Acta A, 2013, 112, 364-376.

25. V. K. Patel and S. Arun, E-J. Chem., 2009, 6, 281- 288.

26. M. U. Rehman, Sci. J. Chem., 2013, 1, 56.

27. M. Mader, A. de Dios, C. Shih, R. Bonjouklian, T. C. Li, W. White, B. L. de Uralde, C. Sanchez-Martinez, M. del Prado, C. Jaramillo, E. de Diego, L. M. M. Cabrejas, C. Dominguez, C. Montero, T. Shepherd, R. Dally, J. E. Toth, A. Chatterjee, S. Pleite, J. Blanco-Urgoiti, L. Perez, M. Barberis, M. J. Lorite, E. Jambrina, C. R. Nevill, P. A. Lee, R. C. Schultz, J. A. Wolos, L. C. Li, R. M. Campbell and B. D. Anderson, Bioorg. Med. Chem. Lett., 2008, 18, 179-183.

28. T. M. Taha, N. H. Ismail, S. Imran, M. Selvaraj, H. Rashwan, F. U. Farhanah, F. Rahim, K. S. Kesavanarayanan and M. Ali, Bioorg. Chem., 2015, 61, 36-44.

29. G. M. Raghavendra, A. B. Ramesha, C. N. Revanna, K. N. Nandeesh, K. Mantelingu and K. S. Rangappa, Tetrahedron Lett., 2011, 52, 5571-5574.
30. J. Perez-Villanueva, R. Santos, A. Hernandez-Campos, M. A. Giulianotti, R. Castillo and J. L. Medina-Franco, Med. Chem. Comm., 2011, 2, 44-49.

31. N. N. Al-Mohammed, Y. Alias, Z. Abdullah, R. M. Shakir, E. M. Taha and A. A. Hamid, Molecules, 2013, 18, 11978-11995.

32. D. Rambabu, P. R. K. Murthi, B. Dulla, M. V. B. Rao and M. Pal, Synthetic Commun, 2013, 43, 3083-3092.

33. M. Arif, M. M. R. Qurashi and M. A. Shad, J. Coord. Chem., 2011, 64, 1914-1930.

34. J. P. Jogi, K. Mounika, M. Padmaja, M. Lakshmi and C. Gyanakumari, E-J Chem, 2011, 8, 1662-1669.

35. A. S. R. Abd El-All, F. A. F. Magd El-Din, A. A. Abdalla, M. M. El-Hefnawi and M. M. El-Rashedy, Global J. Pharm., 2013, 7, 143-152.

36. E. Zamanifar, F. Farzaneh, J. Simpson and M. Maghami, Inorg. Chim. Acta, 2014, 414, 63-70.

37. C. Mukhopadhyay and P. K. Tapaswi,Tetrahedron Lett., 2008, 49, 6237-6240.

38. A. Herbst, C. Bronner, P. Dechambenoit and O. S. Wenger, Organometallics, 2013, 32, 1807-1814.

39. S. Y. Lin, Y. Isome, E. Stewart, J. Liu, D. Yohannes and L. B. Yu, Tetrahedron Lett., 2006, 47, 2883-2886.

40. J. Lu, B. Q. Yang and Y. J. Bai, Synthetic Commun., 2002, 32, 3703-3709.

41. R. P. Karuvalam, K. R. Haridas and S. N. Shetty, J. Chil. Chem. Soc., 2012, 57, 1122-1125.

42. B. Mathew, G. Unnikirishnan, V. P. Shafeer, C. Mohammed Musthafa and P. Femina, Der Pharma Chem., 2011, 3, 627-631.

43. S. Jubie, R. Rajeshkumar, B. Yellareddy, G. Siddhartha, M. Sandeep, K. Surendrareddy, H. S. Dushyanth and K. Elango, J. Pharm. Sci. Res., 2010, 2, 69-76.

44. R. Dubey and N. S. H. N. Moorthy, Chem. Pharm. Bull., 2007, 55, 115-117.

45. A. Farrell, Nat. Med., 2011, 17, 262-265.

46. K. Chen, B. Z. Chu, F. Liu, B. Li, C. M. Gao, L. L. Li, Q. S. Sun, Z. F. Shen and Y. Y. Jiang, Acta Pharmacol. Sin., 2015, 36, 1074-1084.

47. Z. E. Koc and A. Uysal, J. Macromol. Sci. A, 2016, 53, 111-115.

48. A. Kumar, A. Kumar, M. Dubey, A. Biswas and D. S. Pandey, Rsc. Adv., 2015, 5, 88612-88624.

49. I. Ozaytekin and I. Karatas, J. Appl. Polym. Sci., 2008, 109, 1861-1870.

50. S. Uysal, Z. E. Koc, S. Celikbilek and H. Ucan, Synthetic Commun., 2012, 42, 1033-1044.

51. D. W. Hein, R. J. Alheim and J. J. Leavitt, J. Am. Chem. Soc., 1957, 79, 427-29.

52. N. C. Desai, A. M. Dodiya, A. H. Makwana, Med. Chem. Res., 2012, 21, 2320-2328.

53. M. Chandrakala, N. M. N. Gowda, K. G. S. Murthy and K. R. Nagasundara, Magn. Reson. Chem., 2012, 50, 335-340. 
